\title{
PERKEMBANGAN MADRASAH DI INDONESIA
}

\author{
Praptiningsih \\ Institut Islam Mamba'ul Ulum Surakarta (IIM) \\ email:aninglabib@gmail.com.
}

\begin{abstract}
Before madrasah or Islamic school is built, mosque functions generally for holding education and includes every activity. The development of Islamic school firstly comes in three stages: first, mosque, second, institution of Masjid-Khan andthird is Madrasah or Islamic school. Madrasah in Indonesia is Islamic education institution having long history. The trace exploration of the Islamic school is started by efforts of developing Islamic education system conducted by either Islamic figures or socialreligious organizations.

The development is influenced by policies through time, Dutch colonialism period, Japan colonialism period, independence era, old-period, and new period in Indonesia. The regulation of Sisdiknas No.20 in 2003 it is explained "education channel consists of formal education, non formal education and informal education completed and enriched each other. The education stated in verse 1 is held using opened system through meeting and long distance.
\end{abstract}

Keywords: Development, Islamic school, Indonesia

\section{Pendahuluan}

Pendidikan merupakan suatu upaya untuk memberikan penanaman kepribadian yang dapat membawa anak didik kepada perubahan akhlak yang baik, sehingga diharapkan dengan pendidikan generasi muda sebagai penerus bangsa dapat melaksanakan tujuan pendidikan nasional sebagai cita-cita yang terkandung dalam pendidikan itu sendiri. Menurut John Dewey pendidikan adalah rekontruksi atau reorganisasi pengalaman yang menambah makna pengalaman, dan menambah kemampuan untuk mengarahkan pengalaman selanjutnya (Siswoyo, 2008: 18). Menurut UU No. 20 Tahun 2003 tentang Sistem Pendidikan Nasional, "Pendidikan adalah usaha sadar dan terencana untuk mewujudkan suasana belajar dan proses pembelajaran agar peserta didik secara aktif mengembangkan potensi dirinya untuk memiliki kekuatan spiritual keagamaan, pengendalian diri, kepribadian, kecerdasan, akhlak mulia, serta keterampilan yang diperlukan dirinya, masyarakat bangsa dan negara" (Siswoyo, 2008: 19). 
Pendidikan dalam hal ini memiliki peran yang sangat penting dalam pembentukan kepribadian sesuai dengan ajaran agama dan pembentukan generasi yang menjunjung tinggi nilai-nilai bangsa dan negara. Untuk mewujudkan Citacitatersebut perlu adanya sebuah lembaga pendidikan yang menjadi sebuah wadah yang dapat menanamkan, membentuk serta menghasilkan nilai-nilai sebagaimana yang diharapkan. Madrasah merupakan salah satu bentuk lembaga pendidikan yang turut mewarnai perkembangan pendidikan di Indonesia sepanjang sejarah.

Keberadaan madrasah di Indonesia tak lepas dari sejarah perkembangan madrasah dalam dunia Islam. Madrasah dalam Islam tumbuh dan berkembang melewati fase-fase sejarah panjang, seiring dengan pertumbuhan dan perkembangan perjalanan umat Islam dari fase satu ke fase yang lain. Madrasah menjadi salah satu instusi yang tumbuh dalam masyarakat Islam. Keberadaanya pada saat itu sebagai ikon perubahan peradaban masyarakat Islam tentang ilmu pengetahuan, karena kelahiran madrasah sebagai lembaga pendidikan dalam masyarakat Islam berkaitan erat dengan kebutuhan umat Islam akan ilmu pengtahuan. Oleh ketika itu, madrasah tidak lain telah berfungsi sebagai model pendidikan tinggi Islam terutama kemunculannya pada abad pertengahan Islam (Misdar, 2017: 107). Madrasah mengandung arti tempat atau wahana anak mengenyam proses pembelajaran (Fadjar, 1999: 18). Madrasah dalam khasanah kehidupan manusia Indonesia merupakan fenomena budaya yang telah berusia satu abad lebih. Bahkan, bukan suatu hal yang berlebihan, madrasah telah menjadisalah satu wujud entitas budaya Indonesia yang dengan sendirinya menjalani proses sosialisasi yang relatif intensif (Hasbullah, 1996: 66).

\section{Pembahasan}

\section{Sejarah Munculnya Madrasah}

Madrasah merupakan “ isim makan” kata " darasa” dalam bahasa Arab, yang berarti" tempat duduk untuk belajar atau populer dengan sekolah. Pendidikan Islam secara kelembagaan tampak dalam berbagai bentuk yang bervariasi. Di samping lembaga yang bersifat umum seperti masjid, terdapat lembaga-lembaga lain yang mencerminkan kekhasan orientasinya. Secara umum, 
pada abad keempat hijriah dikenal beberapa sisitem pendidikan (madaris altarbiyah) (Maksum, 1999: 51). Madrasah dapat dianggap sebagai tradisi sistem pendidikan bercorak fiqih dan hadist, pada masa kekhalifahan Abbasiyah di Baghdad, madrasah merupakan lembaga pendidikan par excelensi. Setelah perkembangan masjid dan kuttab, madrasah berkembang sangat pesat (Maksum, 1999: 52). Sebelum lahirnya madrasah, masjid merupakan tempat yang paling umum untuk penyelenggaraan pendidikan dan menampung semua kegiatan (Maksum, 1999: 54). Dalam kajian yang lebih terfokus pada madrasah Nizamiyah periode pertengahan di Baghdad, Makdisi mengajukan teori, bahwa asal muasal pertumbuhan madrasah merupakan hasil dari tiga tahap:

Tahap pertama yaitu Tahap masjid, tahap ini berlangsung terutama pada abad-abad kedelapan dan kesembilan. Masjid dalam konteks ini bukanlah masjid yang berfungsi sebagai tempat jama'ah shalat bagi seluruh penduduk kota, yang biasa dikenal dengan masjid jami', masjid raya atau Cathedral Mosqueu Congregatual Mosque. Masjid seperti ini biasanya diatur oleh Negara dan tidak terbuka untuk pendidikan agama bagi umum. Masjid yang dimaksud sebagai tempat pendidikan adalah masjid biasa ( masjid college ) yang di samping untuk tempat jama'ah shalat juga untuk majelis taklim (pendidikan).

Tahap kedua adalah lembaga Masjid-khan, yaitu masjid yang dilengkapi dengan bangunan Khan (asrama, pemondokan), yang masih bergandengan dengan masjid. Berbeda dengan masjid-masjid biasa, masjid-masjid Khan menyediakan tempat penginapan yang cukup representatif bagi para pelajar yang datang dari berbagai kota. Tahapan ini mencapai perkembangan yang sangat pesat pada abad ke-10 (Maksum, 1999: 55). Tahap ketiga, setelah dua tahap perkembangan di atas barulah muncul madrasah yang khusus diperuntukkan sebagai lembaga pendidikan. Madrasah dengan demikaian menyatukan kelembagaan masjid-biasa dengan masjid-khan. Kompleks madrasah terdiri dari ruang belajar, ruang pondokan dan masjid (Maksum, 1999: 56). Lahirnya madarasah-madrasah di dunia Islam, pada dasarnya merupakan usaha pengembangan dan penyempurnaan tempat-tempat pondokan dan masjid yang dipergunakan untuk menampung 
pertumbuhan pengajaran agama Islam, ilmu pengetahuan dan jumlah pelajar yang semakin meningkat dari masa ke masa.

\section{Kebijakan Madrasah Yang Ada di Indonesia dari Masa Ke Masa}

Madrasah di Indonesia merupakan lembaga pendidikan yang berciri khas Islam yang menarik perhatian masyarakat dewasa ini, karena eksistensinya dan peran yang tampak dalam percaturan Pendidikan Nasional (Hawi, 2005: 35). Madrasah sebagai institusi pendidikan keagamaan di Indonesia memiliki sejarah yang panjang. Penelusuran jejak-jejak madrasah dapat dimulai dari upaya-upaya pembaharuan sisitem pendidikan Islam baik yang dilakukan secara pribadi oleh pemimpin-pemimpin Islam maupun yang dilakukan secara institusional lewat organisasi sosial-keagamaan (Maksum, 1999: 57). Bentuk-bentuk pendidikan Islam yang masih sederhana itu adalah cikal bakal madrasah (Maksum, 1999: 58).

Madrasah pertama di Indonesia adalah madrasah Adabiyah di padang (Sumatra Barat), yang didirikan oleh Syeh Abdullah Ahmad pada tahun 1909. Madrasah Adabiyah ini pada mulanya bercorak agama semata-mata, namun kemudian pada tahun 1915 berubah coraknya menjadi HIS (Holand Inland School) Adabiyah. His Adabiyah merupakan sekolah pertama yang memasukkan pelajaran umum ke dalamnya. Selanjutnya pada tahun 1910 didirikan Madrasah School (Sekolah Agama) yang dalam perkembangnnya berubah menjadi Diniyah School (Madrasah Diniyah). Dan nama Diniyah School inilah yang kemudian berkembang dan terkenal.

Setelah itu madrasah Diniyah berkembang hampir seluruh Indonesia, baik merupakan bagian dari pesantren maupun surau, ataupun berdiri di luarnya. Pada tahun 1918 di Yogyakarta berdiri Madrasah Muhammadiyah (Kweekchool Muhammadiyah) yang kemudian menjadi Madrasah Mu'allimin Muhammadiyah, sebagai realisasi dari cita-cita pembaruan Pendidikan Islam yang dipelopori oleh K.H. Ahmad Dahlan. Sebelumya pada tahun 1916 di lingkungan Pondok Pesantren Tebuireng Jombang (Jawa Timur), telah didirikan Madrasah Salafiah oleh K.H. Hasyim Asy'ari, sebagai persiapan untuk melanjutkan pelajaran ke 
pesantren pada tahun 1929 atas usaha Kiai Ilyas, diadakan pembaharuan dengan memasukkan pengetahuan umum pada madrasah tersebut.

Dengan demikian, kita ketahui bahwa permulaan abad ke-20, merupakan masa pertumbuhan dan perkembagan madrasah hampir di seluruh Indonesia, dengan nama dan tingkatan yang bervariasi. Namun madrasah-madrasah tersebut, pada awal perkembangnnya, masih bersifat diniyah semata-mata. Baru sekitar tahun 1930, sedikit demi sedikit, akan tetapi bertambah cepat, dilakukan pembaruan terhadap madrasah dalam rangka memantapkan keberadaannya, khususnya dengan penambahan pengetahuan umum (Hasbullah, 1999: 169). Terlepas dari kenyataan historis yang telah dipaparkan di atas, eksistensi madrasah dalam tradisi Pendidikan Islam di Indonesia tergolong fenomena modern yaitu dimulai sekitar awal abad 20 (Maksum, 1999: 79). Pada awal abad

20 ini merupakan bagian dari gerakan pembaharuan Islam di Indonesia, yang memiliki kontak cukup intensif dengan gerakan pembaharuan di Timur Tengah. Munculnya gerakan pembaharuan di Indonesia pada awal abad 20 dilatar belakangi oleh kesadaran dan semangat yang kompleks.

Dengan menggunakan rentang waktu antara 1900 sampai dengan 1945, Karel A Steenbrink mengidentifikasikan empat faktor yang mendorong gerakan pembaharuan Islam di Indonesia awal abad 20, antara lain: (1) Faktor keinginan untuk kembali pada al-Qur'an dan al-Hadist; (2) Faktor semangat nasionalisme dalam melawan penjajah; (3) Faktor memperkuat basis gerakan sosial, ekonomi, budaya dan politik; (4) Faktor pembaharuan pendidikan Islam di Indonesia ((Maksum, 1999: 83). Berdasarkan penjelasan di atas pembaharuan-pembaharuan mandrasah yang dibuka oleh para tokoh agama tidak hanya mempelajari ilmu- ilmu agama namun sudah mulai di ajarkan ilmu-ilmu umum. Adanya perubahanperubahan tersebutjuga dikarenakan munculnya kebijakan-kebijakan sesuai perkembangan madrasah dari masa-ke masa. Dalam hal ini dapat di klasifikasikan kedalam lima tahap yaitu, masa penjajahan Belanda, masa penjajahan Jepang, masa memasuki era kemerdekaan, masa orde lama dan masa orde baru.

\section{Masa penjajahan Belanda}


Sebagaimana kita ketahui bahwa kedatangan penjajahan Belanda di bumi Nusantara untuk mengemban fungsi ganda, yaitu melakukan penjajahan dan salibisasi. Oleh karena itu, semboyan yang terkenal untuk penjajahan Belanda adalah semboyan 3G, yaitu: Glory(kemenagan atau kekuasaan), Gold (emas atau kekayaan bangsa Indonesia), dan Gospel(upaya salibisasi terhadap umat Islam di Indonesia). Karena misi ganda inilah secara otomatis segala tindakan atau kebijakan yang diambil pihak Belanda dalam masalah pendidikan Islam, cenderung merugikan umat Islam. Bahkan, pemerintah penjajah Belanda secara terangterangan membiayai gerakan misionaris ajaran Kristiani (Aly, 1998: 94).

Meskipun dalam kondisi penjajahan Bealanda, dimana peperangan berkecambuk dimana-mana, akibat agresi Belanda. Madrasah masih tetap dapat berdiri tegak tanpa ada larangan walaupun diberlakukan juga pembatasan perkembangnnya, seperti maklumat Belanda (IS: Indische Staatregeling) Pasal 79 ayat 2 menyebutkan bahwa pengajaran umum adalah netral. Pelajaran agama boleh diberlakukan di luar jam sekolah, sehingga untuk mendirikan madrasah memerlukan izin dari pemerintah Belanda (Misdar, 2017: 24). Politik yang dijalankan pemerintah Bealanda terhadap rakyat Indonesia yang mayoritas beragama Islam sebenarnya didasarkan oleh adanya rasa ketakutan, rasa panggilan Agamanya yaitu Kristen dan rasa kolonialismenya. Sehingga dengan begitu mereka terapkan berbagai peraturan dan kebijakan, di antaranya:

a. Pada tahun 1882 pemerintah Belanda membentuk suatu badan khusus yang bertugas untuk mengawasi kehidupan beragama dan pendidikan Islam yang mereka sebut Priesterraden. Dari nasihat badan inilah maka tahun 1905 pemerintah Belanda mengeluarkan peraturan baru yang isinya bahwa orang yang memberikan pengajaran atau pengajian agama Islam harus terlebih dahulu meminta izin kepada pemerintah Belanda.

b. Tahun 1925 keluar lagi peraturan yang lebih ketat terhadap pendidikan Agama Islam yaitu bahwa tidak semua orang (kiai) boleh memberikan pelajaran mengaji terkecuali telah mendapat semacam rekomendasi atau persetjuan pemerintah Belanda. 
c. Pada tahun 1932 keluar lagi peraturan yang isinya berupa wewenag untuk memberantas dan menutup madrasah dan sekolah yang tidak ada izin, atau memberikan pelajaran yang tidak disukai oleh Belanda yang disebut Ordonasi Sekolah Luar Wilde School Ordonantie (Hasbullah, 1996: 52).

Jika kita melihat peraturan-peraturan pemerintah Belanda yang demikian ketat dan keras mengenai pengawasan, tekanan dan pemberantasan aktivitas madrasah dan pondok pesantren di Indonesia, maka seolah-olah dalam tempo yang tidak lama, pendidikan Islam akan menjadi lumpuh atau porak poranda. Akan tetapi apa yang disaksikan dalam sejarah adalah keadaan yang sebaliknya. Masyarakat Islam di Indonesia pada zaman itu laksana air hujan atau air bah yang sulit dibendung. Dibendung disini meluap disana. Jiwa Islam tetap terpelihara dengan baik. Para ulama dan kiai bersikap non cooperativ dengan Belanda. Mereka mengharamkan kebudayaan yang dibawa oleh Belanda dengan berpegang pada hadist Nabi Muhammmad SAW yang artinya:"Barang siapa yang menyerupai suatu golongan maka ia termasuk golongan tersebut"(Riwayat Abu Dawud dan Imam Hibban). Mereka tetap berpegang kepada ayat Al-Qur'an Surat Al-Maidah ayat 51 yang artinya:"Hai orang-oarang yang beriman, janganlah orang Yahudi dan Nasrani engkau angkat sebagai pemimpinmu" (Zuhairini, 2008: 150).

\section{Masa penjajahan Jepang}

Pada masa pendudukan Jepang, ada satu hal yang istimewa dalam dunia pendidikan, yaitu sekolah-sekolah telah diseragamkan dan dinegerikan meskipun sekolah-sekolah swasta lain seperti Muhammadiyah, Taman Siswa dan lain-lain didizinkan terus berkembang dengan pengaturan dan diselenggarakan oleh penduduk Jepang. Sementara itu, khususnya pada masa awal-awalnya madrasah dibangun dengan gencar-gencarnya selagi ada angin segar yang diberikan oleh Jepang. Walaupun lebih bersifat politis belaka, kesempatan itu tidak disia-siakan begitu saja dan umat Islam Indonesia memanfaatkannya dengan sebaik-baiknya. Ini tampak di Sumatera dengan berdirinya madrasah Awaliyahnya, yang diilhami oleh Majelis Islam Tinggi. 
Hampir seluruh pelosok pedesaan terdapat madrasah Awaliyahyang dikunjungi oleh anak laki-laki dan perempuan. Madrasah Awaliyah ini diadakan pada sore hari dengan waktu kurang satu setengah jam. Materi yang diajarkan ialah belajar membaca AL-Qur'an, ibadah, akhlak dan keimanan sebagai pelatihan pelajaran Agama yang dilakukan di Sekolah Rakyat pagi hari (Aly, 1998: 45). Oleh karena itu, meskipun dunia pendidikan secara umum terbengkalai, karena muridmuridnya setiap hari hanya disuruh gerak badan, baris berbaris, bekerja bakti (romusha), bernyanyi dan sebagainya, madrasah-madrasah yang berada di dalam lingkungan pondok pesantren bebas dar pengawasan langsung pemerintah pendudukan Jepang. Pendidikan dalam pondok pesantren dapat berjalan dengan wajar (Zuhairini, 2008:152). Kebijakan-kebijakan jepang terhadap pendidikan di Indonesia hanyalah semata-mata untuk mengambil hati penduduk Indonesia untuk mendukung pemerintahan Jepang di Indonesia dan membantu Jepang untuk memenagkan perang Asia Timur Raya.

\section{Memasuki Era Kemerdekaan}

Perkembangan madrasah secara kualitatif dapat dicatat setelah dimulainya MWB (Mdrasah Wajib Belajar) pada tahun 1958/1959 sesuai dengan namanya, MWB turut berusaha dalam rangka pelaksanaan undang-undang kewajiban belajar di Indonesia. Dalam hubungan ini MWB diperlakukan sebagai sekolah negeri atau sekolah partikelir yang melaksanakan wajib belajar yang mempunyai hak dan kewajiban (Khozin, 1998: 179).

Dilaksanakannya Madrasah Wajib Belajar ini adalah dengan tujuan:

a. Sesuai dengan namanya, Madrasah Wajib Belajar turut berusaha dalam rangka pelaksanaan undang-undang kewajiban belajar di Indonesia. Dalam hubungan ini Madrasah Wajib Belajar (MWB) akan diperlakukan mempunyai hak dan kewajiabn sebagai sekolah negeri atau sekolah partikelir yang melaksanakan wajib belajar.

b. Pendidikan terutama sekali diarahkan kepada pembangunan jiwa bangsa untuk mencapai kemajuan di lapangan ekonomi, industrialisasi dan transmigrasi. 
Pengorganisasian dan struktur kurikulum serta sistem penyelengaraan MWB tersebut diatur sebagai berikut:

a. MWB adalah tanggung jawab pemerintah baik megenai guru-guru, alatalat, maupun buku-buku pelajarannya, apabila madrasah memenuhi persyaratan yang ditentukan untuk dijadikan MWB.

b. MWB menampung murid-murid yang berumur antara 6-14 tahun. Tujuan MWB adalah untuk mempersiapkan mutu murid untuk dapat hidup mandiri dan mencari nafkah, terutama dalam lapangan ekonomi, industrialisasi dan transmigrasi.

c. Lama belajar MWB adalah 8 tahun.

d. Pelajaran yang diberikan pada MWB terdiri dari tiga kelompok studi, yaitu: pelajaran agama, pengetahuan umum dan pelajaran keterampilan dan kerajinan tangan.

e. $25 \%$ dari jumlah jam pelajaran digunakan untuk pelajaran agama, sedang $75 \%$ untuk pelajaran pengetahuan umum dan ketrampilan atau kerajinan tangan.

Dengan demikian, pelajarannya meliputi:

1) Pelajaran untuk mengembangkan akal disebut kelompok pelajaran pengetahuan alam.

2) Pelajaran untuk mengembangkan perasaan dan kemauan atau hati disebut kelompok pelajaran agama.

3) Pelajaran untuk pengembagan kecekatan dan keterampilan tangan disebut kelompok pelajaran kerajinan tangan.

Dilaksanakan Madrasah Wajib Belajar tersebut, dimaksudkan sebagai usaha awal untuk memberikan bantuan dan pembinaan madrasah dalam rangka penyeragaman materi kurikulum dan sistem penyelenggaraannya, dalam upaya peningkatan mutu Madrasah Ibtidaiyah. Namun ternyata bahwa madarasah dalam bentuk MWB ini, tidak berjalan sebagaimana sebagaimana yang diharapkan. Diantara faktor penyebabnya, disamping keterbatasan sarana dan peralatan, serta guru-guru yang mampu dipersiapkan oleh pemerintah, adalah kurang tanggapnya masyarakat dan pihak-pihak penyelenggara madrasah (Hasbullah, 1998: 179). 
MWB yang semula menjadi tumuan harapan yang ternyata gagal, menjadi pelajaran yang berharga bagi pemeritah. Pemerintah dalam hal ini Depag akhirnya berusaha mencari bentuk madrsah yang lebih ideal. Pilihannya adalah jatuh pada usaha penegerian madrasah (memberikan status negeri kepada madrasah- madrasah swasta) atau mendirikan madrasah-madarsah negeri yang penyelenggaranya langsung di bawah Kementrian Agama. Upaya pembenahan madrasah terus digulirkan. Tahun 1975 pemerintah menggulirkan kebijakan berupa SKB (Surat Keputusan Bersama) 3 Menteri; Menteri Agama; Menteri Pendidikan dan Kebudayaan, dan Menteri Dalam Negeri. Latar belakang munculnya SKB ini sebagaimana tertuang dalam diktum pertimbangannya, yaitu bahwa dalam rangka mencapai tujuan nasional pada umunya dan mencerdaskan kehidupan bagsa pada khususnya, serta memberikan kesempatan yang sama kepada tiap-tiap warga negara Indonesia untuk memperoleh pekerjaan dan penghidupan yang layak bagi kemanusiaan, dan memberikan kesempatan untuk mendapatkan pengajaran yang sama bagi tiap-tiap warga negara, perlu diambil langkah-langkah untuk meningkatkan mutu pendidikan pada madrasah, agar lulusan madrasah dapat melanjutkan atau pindah ke sekolah-sekolah umum dari tingkat Sekolah Dasar sampai Perguruan Tinggi (Khozin, 1998: 80).

Menurut SKB 3 Menteri tersebut yang dimaksud dengan madrasah ialah lembaga pendidikan yang menjadikan mata pelajaran agama Islam sebagai mata pelajaran dasar, yang diberikan sekurang-kurangnya 30\% disamping mata pelajaran umum. Sementara itu madrasah mencakup tiga tingkatan, yaitu:

a. Madrasah Ibtidaiyah, setingkat SD

b. Madrasah Tsanawiyah, setingkat SMP

c. Madrasah Aliyah, setingkat SMA.

Dalam rangka merealisasikan SKB 3 Menteri tersebut, maka pada tahun 1976 Departemen Agama mengeluarkan kurikulum sebagai standar untuk dijadikan acuan oleh Madrasah, baik untuk MI, MTS maupun Madrasah Aliyah.

Kurikulum yang dikeluarkan tersebut, juga dilengkapi dengan:

a. Pedoman dan aturan penyelenggaraan pendidikan dan pengajaran pada madrasah, sesuai dengan aturan yang berlaku pada sekolah-sekolah umum. 
b. Deskripsi berbagai kegiatan dan metode penyampaian program untuk setiap bidang studi, baik untuk bidang studi agama, maupun bidang studi pengetahuan umum.

Dengan diperlakukannya kurikulum standar yang menjadi acuan, maka berarti telah terjadi keseragaman madrasah dalam bidang studi agama, baik kualitas maupun kuantitasnya, kemudian adanya pengakuan persamaan yang sepenuhnya antara madrasah dengan sekolah-sekolah umum yang setaraf, serta madrasah akan mampu berperan sebagai lembaga pendidikan yang memenuhi dan sesuai dengan kebutuhan masyarakat dan mampu berpacu dengan sekolah-sekolahumum dalam rangka mencapai tujuan Pendidikan Nasional.

Adapun SKB 3 Menteri tersebut menetapkan:

a. Ijazah madrasah dapat mempunyai nilai yang sama dengan ijazah sekolah umum yang setingkat.

b. Lulusan madrasah dapat melanjutkan ke sekolah umum setingkat lebih atas.

c. Siswa madrasah dapat berpindah ke sekolah umum yang setingkat.

Untuk pengelolaan madrasah dan pembinaan pendidikan agama menurut SKB 3 Menteri ini, dilakukan oleh Menteri Agama, sedangkan pembinaan dan pengawasan mata pelajaran umum pada madrasah dilakukan oleh Menteri Pendidikan dan Kebudayaan, bersama-sama Menteri Agama dan Menteri Dalam Degeri (Hasbullah, 1998: 102). Kebijakan yang paling akhir yang bersifat umum, tetapi juga langsung berpengaruh terhadap madrasah adalah ditetapkannya UU No 2 tahun 1989 tentang Sistem Pendidikan Nasiaonal. UU itu mengamanatkan bahwa otoritas penyelenggaraan lembaga-lembaga pendidikan, termasuk di dalam lembaga-lembaga pendidikan Islam ada pada Depdikbud, sedangkan Depag hanya memiliki otoritas terhadap pendidikan keagamaan, seperti madrasah diniyah. Praktis dengan dikeluarkannya UU SPN dengan peraturan pemerintah yang menyertainnya, berarti madrasah menjadi sekolah umum (Khozin, 1998: 82).

\section{Masa Orde Lama}


Setelah Indonesia merdeka, penyelenggara pendidikan agama mendapat perhatian serius dari pemerintah, baik di sekolah negeri maupun swasta. Usaha untuk itu dimulai dengan memberikan bantuan terhadap lembaga tersebut sebagaimana yang dianjurkan oleh Badan Pekerja Komite Nasional Pusat (BPKNP) pada tanggal 27 Desember 1945, yang menyebutkan bahwa:Madrasah dan pesantren yang pada hakikatnya adalah suatu alat dan sumber pendidikan dan pencerdasan rakyat jelata yang sudah berurat berakar dalam masyarakat Indonesia umunya, hendaklah pula mendapat perhatian dan bantuan nyata berupa tuntunan dan bantuan material dari pemerintah (Aly, 2017: 127).

Pengembangan madrasah pada masa orde lama (ORLA) bertambah intensif, terutama setelah berdirinya sekolah Pendidikan Guru Agama (PGA) dan Pendidikan Hakim Islam Negeri (PHIN).Kedua macam sekolah tersebut tumbuh dan berkembang dilatarbelakangi oleh dua faktor, pertama, karena kurangnya tenaga pendidik yang siap dalam mengembangkan madrasah dan kurangnya tenaga guru agama, kedua, karena kurangnya tenaga-tenaga profesioal keagamaan di kantor-kantor Kementerian Agama. Dengan berdirinya kedua macam sekolah tersebut niscaya dapat memenuhi tenaga-tenaga professional keagamaan dan juga tenaga-tenaga pendidikan dalam mengembangkan madrasah dan tenaga guru agama yang handal dan professional dalam bidangnya. Semua lembaga pendidikan itu berdirinya setelah kemerdekaan dan tepatnya setelah lahirnya Kementerian Agama (Misdar, 1994: 248).

Perkembangan madrasah pada masa orde lama, sejak awal kemerdekaansangat terkait dengan Departemen Agama yang mulai resmi berdiri 3 januari 1946. Lembaga inilah yang secara intensif memperjuangkan polotik pendidikan Islam di Indonesia. Akhir dekade 1980-an pelaksanaan pendidikan secara nasional masih bertumpu pada Undang-undang No.4 Tahun 1950 jo. No. 12 Tahun 1954 “Tentang Dasar-Dasar Pendidikan dan Pengajaran di Sekolah". Undang-undang ini pada dasarnya merupakan usaha untuk memenuhi rekomendasi Badan Pekerja Komite Nasional Indonesia Pusat (BP-KNIP) 17 Desember 1945, yang menuntut adanya pembaharuan pendidikan dan pengajaran di Indonesia. Salah satu rekomendasi itu menyangkut pendidikan agama, yaitu 
sebagai berikut (Maksum, 1999: 129): pengajaran agama hendaklah mendapat tempat teratur seksama, hingga cukup mendapatkan perhatian yang semestinya dengan tidak mengurangi kemerdekaan golongan-golongan yang berkehendak mengikuti kepercayaan yang dipeluknya. Tentang cara melakukan ini baiklah Kementerian mengadakan perundingan dengan Badan Pekerja.

Madrasah dan pesantren-pesantren yang pada hakekatnya adalah salah satu alat dan sumber pendidikan dan pencerdasan rakyat jelata yang sudah berurat berakar dalam masyarakat Indonesia umumnya hendaklah pula mendapat perhatian dan bantuan yang nyata dengan berupa tuntunan dan bantuan materil dari pemerintah.Pada tanggal 3 Desember 1960, keluar ketetapan MPR No. II / MPRS/ 1960 tentang “ Garis-Garis Besar Pola Pembangunan Nasional Semesta Berencana, Tahapan Pertama tahun 1961-1969.” Dalam kaitannya dengan pendididkan nasioal, ketetapan ini antara lain menyebutkan bahwa pendidikan agama menjadi mata pelajaran di sekolah-sekolah mulai dari sekolah rakyat sampai dengan Universitasuniversitas Negeri, dengan pengertian bahwa murid- murid berhak tidak ikut serta, apabila wali murid/ murid dewasa menyatakan keberatannya.

Ketetapan ini mamang tidak mengubah status pendidikan agama sebagai mata pelajaran minor/ pilihan, tetapi telah memperluas jangkauannya sampai tingkat Universitas. Perubahan seperti ini tentu belum banyak berarti, apalagi dalam pelaksanaannya dihadapkan pada situasi politik NASKOM (yang memberi peran langsung bagi partai komunis Indonesia dalam pemerintahan). Namun demikian, dalam kaitannya dengan madrasah, ketetapan ini telah memberi perhatianmeskipun tidak terlalu berartidengan merekomendasikan agar madrasahberdiri sendiri sebagai badan otonom di bawah pengawasan Departemen Agama dan bukan di bawah pengawasan Departemen Pendidikan dan Kebudayaan”. Dengan rekomedasi ini, madrasah tetap berada di sisitem pendidikan nasional, tatapi usulannya yang konkrit dalam ketetapan itu sudah merupakan langkah pengakuan akan eksisitensi madrasah dalam kerangka pendidikan nasional (Maksum, 1999: 131). 


\section{Masa Orde Baru}

Pada masa orde baru, perkembangan madrasah banyak terjadi perubahan terutama dalam perkembangan kebijakan yang dikeluarkan oleh pemerintah. Meskipun kebijakan yang dikeluarkan itu bersifat melanjutkan dan memperkuat serta memperbaiki kebijakan yang ada pada masa orde lama (Misdar, 1994: 249). Secara umum diakui bahwa kebijakan pemerintah orde baru mengenai pendidikan agama, termasuk madarsah, bersifat positif dan konstruktif, khusunya dalam dua dekade terakhir 1980-an-1990-an. Pemerintah orde baru memandang bahwa lembaga itu harus dikembangkan dalam rangka pemerataan kesempatan dan peningkatan mutu pendidikan. Kebijakan seperti ini secara lebih kuat tercermin dalam komitmen orde baru untuk menyelenggarakan pendidikan agama sebagai bagian yang tidak terpisahkan dari Sistem Pendidikan Nasional.

Pada masa-masa awal pemerintahan orde baru, kebijkan dalam beberapa hal mengenai madrasah bersifat melanjutkan dan memperkuat kebijakan orde lama. Pada tahap ini madrasah belum di pandang sebagai bagian dari sistem pendidikan secara nasional, tetapi merupakan lembaga pendidikan otonom di bawah pengawasan Menteri Agama. Hal ini disebabkan karena kenyataan bahwa sistem pendidikan madrasah lebih didominasi oleh muatan-muatan agama. Menggunakan kurikulum yang belum berstandar, memiliki struktur yang tidak seragam, dan memberlakukan managemen yang kurang dapat dikontrol oleh pemerintah. Mengahadapi kenyataan ini, maka langkah pertama dalam pembaharuan pendidikan madrasah adalah melakukan formalisasi dan strukturisasi madrasah. Formalisasi ditempuh dengan menegerikan sejumlah madrasah dengan kriteria tertentu yang diatur oleh pemerintah, di samping mendidrikan madrasah-madrasah negeri yang baru. Sedangkan strukturisasi dilakukan dengan mengatur penjenjangan dan perumusan kurikulum yang cenderung sama dengan penjenjangan dan kurikulum sekolah-sekolah di bawah Departemen Pendidikan dan kebudayaan.

Pada tahap berikutnya, antara akhir 70-an sampai dengan akhir 80-an, pemerintah orde baru mulai memikirkan kemungkinan mengintegrasikan madrasah ke dalam Sistem Pendidikan Nasional. Usaha menuju ke arah ini 
agaknya tidak sederhana karena secara konstitusional pendidikan nasional masih diatur oleh UU No.4 Tahun 1950 jo. No 12 Tahun 1954 yang mengabaikan pendidikan madrasah. Apa yang bisa dilakukan pemerintah pada tahap ini adalah memperkuat strutur madrasahbaik dalam jenjang maupun kurikulumya, sehingga lulusannya memperoleh pengakuan yang sama dengan lulusan sekolah dan dapat melanjutkan ke jenjang pendidikan yang lebih tinggi di sekolah-sekolah yang dikelola Departemen Pendidikan dan Kebudayaan. Untuk tujuan ini dikeluarkan kebijakan berupa Keputusan Bersama Tiga Menteri pada tahun 1974 tentang peningkatan mutu pendidikan pada madrasah.

Memasuki dekade 90-an, kebijakan pemerintah orde baru mengenai madrasah ditinjau secara penuh untuk membangun satu sistem Pendidikan nasional yang utuh. Dengan satu sistem yang utuh dimaksudkan bahwa pendidikan nasional tidak hanya bergantung pada pendidikan jalur sekolah tetapi juga memanfa'atkan jalur luar sekolah. Untuk tujuan ini, pemerintahanorde baru melakukan langkah konkrit berupa penyusunan Undang-Undangan No. 2 tahun 1989 tentang Sistem pendidikan Nasional dan sekaligus menggantikan UU No. 4 Tahun 1950 jo. No. 12 Tahun 1954. Penegasan definitif tentang madrasah diberikan melalui keputusankeputusan yag lebih operasional dan dimaksudkan dalam kategori pendidikan sekolah tanpa menghilangkan karakter keagamaannya. Melalui upaya ini dapat dikatakan bahwa madrasah berkembang secara terpadu dalam sistem Pendidikan nasional (Maksum, 1999: 132).

\section{Kebijakan Pemerintah Pada Madrasah Dalam Sisdiknas No.20 Tahun 2003.}

Antara pendidikan Islam dan pendidikan nasional Indonesia tak dapat dipisahkan satu dengan yang lain. Hal ini dapat ditelusuri dari dua segi, pertama dari konsep penyusunan sistem pendidikan nasional Indonesia itu sendiri, dan yang kedua dari hakikat pendidikan Islam dalam dalam kehidupan beragama kaum muslimin di Indonesia. Penyusunan-penyusunan suatu sistem pendidikan nasional harus mementingkan masalah-masalah eksistensi umat manusia pada umunya dan eksistensi bangsa Indonesia pada khususnya dalam hubungannya 
dengan masa lampau, masa kini dan kemungkinan-kemungkinan perkembangan masa dating (Zuhairini, 2017: 231).

Kaitan antara pendidikan Islam dengan pendidikan nasional akan semakin nampak dalam rumusan pendidikan nasional hasil rumusan Komisi Pembaharuan Pendidikan Naional, yaitu bahwa pendidikan nasional ialah usaha sadar untuk membagun manusia Idonesia seutuhnya, yaitu manusia yang bertaqwa kepada Tuhan Yang Maha Esa, dengan mengusahakan perkembangan kehidupan beragama, kehidupan yang berkepercayaan terhadap Tuhan Yang Maha Esa, nilai budaya, pengetahuan, keterampilan, daya estetik, dan jasmaninya, sehingga ia dapat mengembangkan dirinya dan bersama-sama dengan sesame manusia membangun masyarakatnya, serta membudayakan alam sekitar (Maksum, 1999: 234). Pengembangan sistem pendidikan madrasah dilakukan oleh pemerintah didasarkan kepada Undang-Undang No. 20 Tahun 2003 pada pasal 13 dinyatakan bahwa, “ Jalur pendidikan terdiri atas pendidikan formal, non formal, dan informal yang dapat saling melingkapi dan memperkaya. Pendidikan sebagaimana dimaksud dalam ayat 1 deselenggarakan dengan sistem terbuka melalui tatap muka dan atau melalui jarak jauh".

Pasal tersebut menjelaskan bahwa pendidikan madrasah pun diselenggarakan dengan sistem terbuka, baik melalui tatap muka mupun jarak jauh. Untuk pengembangannya, madrasah sebagai sekolah pendidikan ilmu agamaIslam yang juga mengajarkan ilmu-ilmu umum secara islami (Saebani, 2010: 248). Dari kebijakan di atas dalam Sisdiknas No. 20 Tahun 2003 juga muncul kebijakan dalam BabVIII yang maksudnya adalah bahwa setiap warga negara Indonesia wajib belajar minimal sekolah dasar dan tanpa adanya pungutan biaya yang mana telah ditetapkan oleh DPR RI dan Presiden Indonesia dalam UU Sistem Pendidikan Nasional yang tercantum dalam Bab 1 No. 18 yang berbunyi bahwa wajib belajar adalah program pendidikan minimal sekolah dasar yang harus diikuti oleh semua warga Indonesia atas tanggung jawab pemerintah dan pemerintah daerah (Oktradisa, 2011: 131).

Pengembangan sistem pendidikan madrasah telah benar-benar melibatkan pemerintah, terbukti banyaknya masalah negeri. Dulu, pendidikan madrasah 
mayoritas swasta. Dalam pasal 16 dinyatakan bahwa "Jalur, jenjang, dan jenis penidikan dapat diwujudkan dalam bentuk satuan pendidikan yang diselenggarakan oleh pemerintah, pemerintah daerah, dan atau masyarakat." Kesederajatan sistem pendidikan madrasah formal antara Sekolah Dasar dengan Ibtidaiyyah, sekolah menengah pertama dengan madrasah Tsanawiyah, sekolah memengah atas dengan Madrasah Aliyah, dan adanya perguruan tinggi agama Islam menunjukkan pengembangn sistem pendidikan agama yang sangat luarbiasa. Kini madrasahmadrasah yang ada di Indonesia kedudukannya sama dengan pendidikan formal lainnya, bahkan pendidikan madrasah lebih unggul dari materi pelajaran yang diberikan anak didiknya, yaitu menggabungkan dua materi pelajaran yang sistematis, antara materi pelajaran agama dan pelajaran umum (Oktradisa, 2011: 244).

\section{Keterkaitan Pendidikan Islam dan Pendidikan Nasional}

Antara pendidikan Islam dan pendidikan nasional Indonesia tak dapat dipisahkan satu dengan yang lain. Hal ini dapat ditelusuri dari dua segi, pertama dari konsep penyusunan sistem pendidikan nasional Indonesia itu sendiri, dan yang kedua dari hakikat pendidikan Islam dalam dalam kehidupan beragama kaum muslimin di Indonesia. Penyusunan-penyusunan suatu sistem pendidikan nasional harus mementingkan masalah-masalah eksistensi umat manusia pada umunya dan eksistensi bangsa Indonesia pada khususnya dalam hubungannya dengan masa lampau, masa kini dan kemungkinan-kemungkinan perkembangan masa dating (Zuhairini, 2017: 232).

Kaitan antara pendidikan Islam dengan pendidikan nasional akan semakin Nampak dalam rumusan pendidikan nasional hasil rumusan Komisi Pembaharuan Pendidikan Naional, yaitu bahwa pendidikan nasional ialah usaha sadar untuk membagun manusia Idonesia seutuhnya, yaitu manusia yang bertaqwa kepada Tuhan Yang Maha Esa, dengan mengusahakan perkembangan kehidupan beragama, kehidupan yang berkepercayaan terhadap Tuhan Yang Maha Esa, nilai budaya, pengetahuan, keterampilan, daya estetik, dan jasmaninya, sehingga ia 
dapat mengembangkan dirinya dan bersama-sama dengan sesame manusia membangun masyarakatnya, serta membudayakan alam (Zuhairini, 2017: 234).

Menurut Undang-Undang Sisdiknas nomor 20 tahun 2003 tentang Sistem Pendidikan Nasional. Pendidikan adalah usaha sadar dan terencana untuk mewujudkan suasana belajar dan proses pembelajaran agar peserta didik secara aktif mengembangkan potensi dirinya untuk memiliki kekuatan spiritual keagamaan, pengendalian diri, kepribadian, kecerdasan, akhlak mulia, serta keterampilan yang diperlukan dirinya, masyarakat bangsa dan negara (Siswoyo, 1997: 19). Dalam Undang-Undang Sisdiknas Nomor 20 tahun 2003 dinyatakan pada pasal 1 Ayat 5 bahwa, Pendidikan Nasional adalah pendidikan yang berdasarkan Pancasila dan Undang- Undang Dasar Negara Republik Indonesia Tahun 1945 dan perubahannya yang bersumber pada ajaran agama, keanekaragaman budayaIndonesia, serta tanggap terhadap perubahan zaman (Nizar, 2004: $x)$.

\section{PENUTUP}

Madrasah awalnya adalah sebuah masjid yang di gunakan disamping untuk ibadah juga di gunakan pendalaman ilmu pengetahuan. Madrasah muncul pada abad keempat hijrah dikenal beberapa sisitem pendidikan (Madaris Al-tarbiyah). Yang sistem pendidikannya bercorak fiqih dan hadist, pada masa kekhalifahan Abbasiyah di Baghdad. Eksistensi madrasah dalam tradisi Pendidikan Islam di Indonesia tergolong fenomena modern yaitu dimulai sekitar awal abad 20.Pembaharuan mandrasah di Indonesia dilakukan oleh para tokoh agama dan organisasi Islam di Indonesia. Pembaharuan tersebut muncul karena di dasari oleh perkembangan umat islam itu sendiri serta adanya kebijakan- kebijakan yang muncul dari zaman penjajahan yaitu masa penjajahan Belanda, masa penjajahan Jepang samapi, memasuki era kemerdekaan, masa orde lama dan masa orde baru.

Madrasah pada masa penjajahan Belanda masih tetap dapat berdiri tegak meski diberlakukan pembatasan perkembangnnya, untuk mendirikan madrasah memerlukan izin dari pemerintah Belanda. Masyarakat Islam di Indonesia pada 
zaman itu laksana air hujan atau air bah yang sulit dibendung. Dibendung disini meluap disana. Jiwa Islam tetap terpelihara dengan baik. Para ulama dan kiai bersikap non cooperativ dengan Belanda. Pada masa pendudukan Jepang, ada satu hal yang istimewa dalam dunia pendidikan, yaitu sekolah-sekolah telah diseragamkan dan dinegerikan meskipun sekolah-sekolah swasta lain seperti Muhammadiyah, Taman Siswa dan lain-lain didizinkan terus berkembang dengan pengaturan dan diselenggarakan oleh penduduk Jepang. Kebijakan tersebut hanyalah semata-mata untuk mengambil hati penduduk Indonesia untuk mendukung pemerintahan Jepang di Indonesia dan membantu Jepang untuk memenagkan perang Asia Timur Raya.

Memasuki era kemerdekaan Perkembangan madrasah secara kualitatif dapat dicatat setelah dimulainya MWB (Madrasah Wajib Belajar) pada tahun 1958/1959 dan pada tahun 1975 pemerintah menggulirkan kebijakan berupa SKB (Surat Keputusan Bersama) 3 Menteri; Menteri Agama; Menteri Pendidikan dan Kebudayaan, dan Menteri Dalam Negeri. Untuk pengelolaan madrasah dan pembinaan pendidikan agama menurut SKB 3 Menteri ini, dilakukan oleh Menteri Agama, sedangkan pembinaan dan pengawasan mata pelajaran umum pada madrasah dilakukan oleh Menteri Pendidikan dan Kebudayaan, bersama-sama Menteri Agama dan Menteri Dalam Degeri.

Pengembangan madrasah pada masa orde lama (ORLA) bertambah intensif, terutama setelah berdirinya sekolah Pendidikan Guru Agama (PGA) dan Pendidikan Hakim Islam Negeri(PHIN). Perkembangan madrasah pada masa orde lama, sejak awal kemerdekaansangat terkait dengan Departemen Agama yang mulai resmi berdiri 3 januari 1946. Madrasahberdirisebagai bagian dari sistem pendidikan secara nasional, tetapi merupakan lembaga pendidikan otonom di bawah pengawasan Menteri Agama. Pada masa-masa awal pemerintahan orde baru, madrasah belum di pandang sebagai bagian dari sistem pendidikan secara nasional, tetapi merupakan lembaga pendidikan otonom di bawah pengawasan Menteri Agama. Langkah pertama dalam pembaharuan pendidikan madrasah padamasa orde baru ini adalah melakukan formalisasi dan strukturisasi madrasah.Memasuki dekade 90-an, kebijakan pemerintah orde baru mengenai 
madrasah ditinjau secara penuh untuk membangun satu sistem pendidikan nasional yang utuh. Melalui upaya ini dapat dikatakan bahwa madrasah berkembang secara terpadu dalam sistem pendidikan nasional.

Kaitan antara pendidikan Islam dengan pendidikan nasional akan semakin nampak dalam rumusan pendidikan nasional hasil rumusan Komisi Pembaharuan Pendidikan Nasional, yaitu bahwa pendidikan nasional ialah usaha sadar untuk membagun manusia Idonesia seutuhnya, yaitu manusia yang bertaqwa kepada Tuhan Yang Maha Esa, dengan mengusahakan perkembangan kehidupan beragama, kehidupan yang berkepercayaan terhadap Tuhan Yang Maha Esa, nilai budaya, pengetahuan, keterampilan, daya estetik, dan jasmaninya, sehingga ia dapat mengembangkan dirinya dan bersama-sama dengan sesama manusia membangun masyarakatnya, serta membudayakan alam sekitar.

Pengembangan sistem pendidikan madrasah dilakukan oleh pemerintah didasarkan kepada Undang-Undang No. 20 Tahun 2003 pada pasal 13 dinyatakan bahwa, "Jalur pendidikan terdiri atas pendidikan formal, non formal, dan informal yang dapat saling melingkapi dan memperkaya. Pendidikan sebagaimanadimaksud dalam ayat 1 deselenggarakan dengan sistem terbuka melalui tatap muka dan atau melalui jarak jauh”.Kesederajatan sistem pendidikan madrasah formal antara Sekolah Dasar dengan Ibtidaiyyah, sekolah menengah pertama dengan madrasah Tsanawiyah, sekolah memengah atas dengan Madrasah Aliyah, dan adanya perguruan tinggi agama Islam menunjukkan pengembangn sistem pendidikan agama yang sangat luar biasa. Kebijakan pemerintah terhadap madrasah dalam Sisdiknas No.20 Tahun 2003 yaitu “ Jalur pendidikan terdiri atas pendidikan formal, non formal, dan informal yang dapat saling melingkapi dan memperkaya. Pendidikan sebagaimana dimaksud dalam ayat 1 deselenggarakan dengan sistem terbuka melalui tatap muka dan atau melalui jarak jauh".

\section{Daftar Pustaka}

Basri Hasandan SaebaniAhmadBeni.2010. Ilmu Pendidikan Islam.Bandung: Pustaka Setia. 
Hasbullah.1996. Kapita Selekta Pendidikan Islam. Jakarta: Raja Grafindo Persada.

Hasbullah, 999. SejarahPendidikan Islam di Indonesia, lintas Sejarah Pertumbuhan dan Perkembangan. Jakarta: PT Raja Grafindo Persada.

HawiAkmal. 2005. Kapita Selekta Pendidikan Islam. Palembang: IAIN Raden Patah Press.

Khozin. 2001. Jejak-Jejak Pendidikan Islam di Indonesia. Malang: UMM Press.

Maksum. 1999. Madrasah Sejarah \& Perkembgannya. Jakarta: Logos Wacana Ilmu.

MalikFadjar. 1999.Madrasah dan Tantangan Modernitas.Bogor: Mizan.

MisdarMuh. 2017.Sejarah Pendidikan Dalam Islam. Jakarta: Raja Wali Pers.

Mustafa dan AlyAbdullah. 1998.Sejarah Pendidikan Islam di Indonesia (SPII). Bandung: Pustaka Setia.

Dwi Siswoyo dkk. 2008. Ilmu Pendidikan. Yogyakarta: UNY Press.

Supriyanto Didikdan OktradisaAhwiy. 2011.Bunga Rampai Pendidikan Islam.Surabaya:Taruna Media Pustak.

Zuhairini dkk. 2008.Sejarah Pendidikan Islam. Jakarta: Bumi Aksara. 